\title{
The Form of Justice in Resolving Capital Market Dispute Resolution
}

\author{
Ayup Suran Ningsih ${ }^{1, *}$ \\ ${ }^{1}$ Department of Private-Commercial Law Faculty of Law, Universitas Negeri Semarang, Indonesia \\ *Corresponding author. Email: ayuupp@mail.unnes.ac.id
}

\begin{abstract}
The Indonesia Capital Market Arbitration Board (BAPMI), established to settle capital markets disputes when there is a written agreement between the disputing parties. is the article aims to explain that BAPMI is expected to resolve disagreements capital markets more effective than court and managed by people who understand the ins and outs of the stock market, due to a prolonged dispute resolution will only cause harm and increase business risk. The parties may apply to the District Court to cancel if it is suspected that the decision contains a misleading message, letter, or forged documents. BAPMI is the effective way and the best place to resolve capital market dispute. BAPMI is one of Alternative Dispute Resolution (ADR), it can be concluded that ADR is a new form of justice that society should pursue in the future.
\end{abstract}

Keywords: BAPMI, capital markets, dispute resolution.

\section{INTRODUCTION}

Capital markets are activities related to the public offering and trading of securities, public companies related to the securities issued, and institutions and professions associated with the effect.[1] Capital market, as the market in general, is a gathering place for sellers and buyers. What distinguishes it from other markets is on the object being marketed. If in the general market traded is something concrete[2], such as daily necessities, but which are traded in the capital markets is capital or funds in the form of securities (securities).[3] In other words, the stock market is the liaison between investors (owners of funds) with firms or institutions that require funding through long-term trading instruments (stocks, bonds, rights issues, etc.). Business Development include capital market in Indonesia undergoing rapid change. [4] The capital market is considered as one of the most effective ways to accelerate the development of a country and become one of the important pillars of the investment community, as well as a source of financing for Indonesian companies. As financial instruments, capital markets can only be developed adequately if it is based on the principles of fair, transparent, and secure.
There are 6 characteristics of the ideal and essential in the implementation of the capital market, are:[5]

1. Healthy

2. Transparent

3. Efficient

4. The application of the law.

5. The international standard.

6. Supervision by an independent

The capital market is one of the institutions that are designed for economic development and play an important role in a country's financial sector.[6] Capital markets offer a new alternative[7] to the world of business to obtain financing from companies and investors that invest outside the investment banking and other activities. As a result, the state or the government has no reason to participate in directing the dynamics of capital markets. Changes in capital market development in Indonesia is not only a positive impact, but also lead to disagreements and conflicts or disputes that cannot be avoided by the parties.[8] 
Of course, any disputes arising must be resolved quickly and accurately so that the dispute is not prolonged. More and more commercial activity, the greater the risk of disputes to be resolved. Business relationships and agreements, there is always the possibility of conflict.[9] Basically, no one wants to quarrel with others. Due to engage in trade or agreement, each party must anticipate the possibility of disputes that may arise at any time in the future.[10] Disputes are to be anticipated is how to implement the clauses of the agreement, what was in the treaty or whether it was caused by other factors.[11] In essence, the law of Indonesia has provided a way to resolve disputes between the parties.[12] Things that can be done by the parties include, among others, general judicial proceedings (litigation) and through a process outside the court (not litigation). The use of alternative dispute resolution methods (non-litigation) to resolve the trade dispute has long been a choice. Indeed, the court process is time consuming and complicated: a win-loss procedure that has not been able to meet the common interests, is likely to cause new problems, requiring high cost, no charge response, creating hostility between the parties to the dispute. Due to some shortcomings in the court dispute resolution, some people prefer the resolution of unlawful or non-litigation.[13] To settle the dispute out of court (without litigation), some forms can be selected, through negotiation, mediation, conciliation, expert assessment, consultation, and arbitration. It is associated with increased perceived barriers to the use of public judicial institution as a place of dispute resolution at the national and international levels, which is a strong motivation for the parties to the dispute chose another way to resolve his case out of court.[14]

Arbitration is one way to resolve the dispute is most preferred by businessmen, regarded as the most harmonious way to meet the needs of the business world. In fact, the arbitration court is considered an independent contractor to resolve the dispute in accordance with their wishes and needs.[15] Disputes between capital market participants are usually driven by economic policy, including a growing role in the capital markets sector, which created discord among the various parties. [8] One way to resolve disputes of financial markets is the establishment of an arbitration institution, supported by regulations issued by the Capital Market Supervisory Agency and Financial Institution (Bapepam-LK), namely: the Capital Market Law No. 8, 1995 and the regulations of the Capital Market Supervisory Agency and Financial Institution.[16]
Furthermore, with the support of the Capital Market Supervisory Agency (Bapepam), in 2002, the Self-Regulatory Organization (SRO) in the capital market, the Jakarta Stock Exchange (JSX) and the Securities Exchange Stock Surabaya (BES) is now the Indonesian Stock Exchange (BEI), Corporate Guarantee and Indemnity Indonesia (KPEI) and Indonesian Central Securities Depository (KSEI) as well as 17 associations working in the capital markets sector in Indonesia signed a Memorandum of Understanding $\mathrm{MoU}$ (Memorandum of Understanding) (Deed No. 14, prepared by Notary Fathiah Helmy SH) to form an arbitration institution was subsequently appointed as the Indonesian Capital Market arbitration Board (here in after referred to BAPMI). BAPMI[17] is a private organization, non-profit, independent, and neutral, free from any party intervention. This is a fundamental requirement for an institution that offers a way to resolve disputes. The Indonesian Capital Market Arbitration Board (Badan Arbitrase Pasar Modal Indonesia "BAPMI") was established as a forum to settle any civil disputes in capital market through out-of-court settlement mechanisms. Currently, BAPMI provide four methods of alternative dispute resolution, which are Binding Opinion, Mediation, Adjudication, and Arbitration.[17] With four methods of settlement, a decision must result in a mutually beneficial solution for both parties. The existence BAPMI expected to facilitate capital market dispute resolution through non-litigation procedure, the agency is required to resolve the dispute required capital markets to be more effective in terms of time and cost than in the past. BAPMI as independent court that is run by people who understand the ins and outs of the stock market. Settlement of disputes protracted will only cause harm and increased business risk.

\section{RESEARCH METHOD}

This research is conducted by juridicalnormative method[18] by studying and examining legal principles, especially positive legal principles derived from existing literature from statutory regulations and provisions relating to capital market law and alternative disputes resolution in capital market area. This normative legal research is carried out using a statute approach, in order to enrich the considerations of appropriate legal considerations to deal with prevailing legal problems. Besides that, it also shows that the results of normative legal research that answer legal problems are concrete and factual.[19] 


\section{FINDINGS AND DISCUSSION}

\subsection{Capital Markets Dispute Settlement Mechanism by BAPMI}

Settlement through non-litigation is a resolving dispute out of court settlement.[20] Disputes are resolved outside the court was closed to the public (closed session) and the confidentiality of the parties is guaranteed, the process is faster and more efficient[21]. The process of dispute resolution outside the court avoids the procedural and administrative delays, such as in public court proceedings, and offers a win-win solution out of court.[22] Alternative Dispute Resolution here in after called or known as ADR. To ensure the successful implementation of the ADR mechanism, a prerequisite in the form of key success factors must be known. Key success factors of the ADR are[23], First, Disputes are always within "reasonable limits". ADR will be effective if the dispute between the parties is still enacted in natural state. The level of litigation that goes beyond a reasonable threshold would be difficult to be solved by the method of ADR. Such disputes are generally making the relationship between the parties is very bad, so that between the parties there is no desire to solve problems with win-win solutions (using ADR). In such situations, it would be difficult to make a decision that can be accepted by both sides.

Second, Commitment of the Parties. The involvement of the party's dispute resolution ADR success depends on the good faith of the parties, so that the disputing parties to take responsibility for their own decisions and the validity of ADR depending on your level of commitment. and acceptance process of ADR of the parties to the dispute. Therefore, if the parties do not start with a good resolve ADR, ADR process would be useless, unproductive, and only going to spend money and time.

Third, Relationships Sustainability. Relationship sustainability Settlement through the ADR based on the spirit of win-win solutions. Therefore, considering the interests of the future, the disputing parties must expect to maintain their good relationship. This will encourage them not only to think about the result that is beneficial to them, but also about the process to achieve it.

Alternative Dispute Resolution (ADR) is a means of dispute resolution in addition to means which are generally made by the people (the courts)
ADR is also called alternative court settlement (outof-court dispute settlement), although today the implementation of one of the mechanisms of ADR, is mediation, have also implemented as part of civil proceedings.[24] Alternative Dispute Resolution (ADR). ADR is referred to as alternative settlement out of court or out-of-court dispute settlement. ADR has several mechanisms that can be chosen by the parties to solve his case, some of the Alternative Dispute Resolution of the most popular are:[25]

1. Mediation

Mediation by the Supreme Court Regulation No. 1 of 2016 on Mediation Procedure of the Court (Supreme Court Regulation No. 1 of 2016) explains:

"Mediation is a way of settling disputes through negotiation process to obtain the agreement of the parties with the assistance of a mediator".

2. Conciliation

Conciliation is a continuation of the mediation. Mediator function is changed into a conciliator. In this case the function conciliator more active in seeking other forms of dispute resolution, and then offered to the parties. If the parties agree, the solution made by a conciliator be a resolution, an agreement is final and binding on the parties.

\section{Expert Rating}

Assessment expert or also commonly referred to as a statement of expert opinion was requested by the litigants with experts. In particular, the expert who is considered a better understanding of the disputed material. Membership request due to disagreements between the two parties. Requested the opinion of experts, both about controversy and beyond that, if necessary, or in other words, the opinion of experts generally aim to clarify the question disputed by the parties.

4. Negotiations

Negotiation is an effort to reach an agreement with another party through a process of interaction, a dynamic communication to obtain a solution or a solution to an ongoing problem. Negotiations are usually done in cases that are not too complicated. A critical element of the negotiations is the good faith of the parties to sit together and resolve the issue. 


\section{Arbitration}

Article 1 Paragraph (1) of Law No. 30 of 1999 on Arbitration and Alternative Dispute Resolution Arbitration is clear that:

"How Settlement out of court a dispute in general based on the arbitration agreement made in writing by the parties to the dispute."

ADR definition governed by Article 1 (10) of Law No. 30 In 1999, ADR as an institution entrusted with the settlement of disputes or disputes in accordance with the procedures agreed upon by the parties, i.e., the court settlement resulting from the consultation, negotiation, mediation, conciliation or expert judgment and arbitration. Way of solving this ADR are also adopted by BAPMI in resolving disputes in the areas of capital markets, through Mediation, Opinion Binding, Adjudication and Arbitration. One of the policies in the economic field, especially in the form of an increased role in the capital market, enabling the emergence of disputes between the various parties. One way of solving disputes in the capital market sector is the establishment of an arbitration institution, supported by the rules set by the Capital Market Supervisory Agency and Financial Institution (Bapepam-LK, Now, The Institution is Financial Authority Service or in Bahasa called Otoritas Jasa Keuangan (OJK)), called Law No. 8 of 1995 on Capital Market and the regulations of the Capital Market Supervisory Agency and Financial Agency.

With the support of Bapepam-LK, some companies such as Jakarta Stock Exchange (JSX), Surabaya Stock Exchange (BES), Indonesian Clearing and Guarantee Corporation (KPEI) and PT. Save the Securities Depository Indonesia (KSEI) and 17 associations in Indonesian Capital Market Environment made an agreement to establish an arbitration institution.[17] During the period from August 2002 until January 2003, BAPMI issued several procedural rules, pointing to some experts in the field of financial markets as an arbitrator / mediator BAPMI and ratify the Council of Honor BAPMI. Since then, BAPMI fully operational. BAPMI provide dispute resolution services at the request of the parties to the dispute through dispute settlement mechanisms outside the court. However, all disputes cannot be resolved through BAPMI.[26]

BAPMI offers four types[17] of dispute resolution outside the court that can be chosen by the parties to the dispute, are mediation, binding opinion, adjudication, and Arbitration. By fulfilling its role as an institution of alternative conflict resolution, BAPMI ensure neutrality and independence. BAPMI not allow anyone to act as an arbitrator/mediator in the dispute if the parties related to the affiliate or conflict of interest with a specific case or with one of the parties to the dispute. If an affiliate or a conflict of interest is found later, the arbitrator/mediator will be replaced by others who are neutral and independent.

The purpose of creating BAPMI not be separated from the willingness of the Indonesian capital market players to have a dispute resolution institutions extrajudicial especially in the field of financial markets which is managed by people who understand the capital market, with the decisionmaking process that is fast and economical, final and binding. And a sense of fairness.[27]

BAPMI dispute resolution process carried out by sending authority to a third party neutral and independent (called arbitrators) who review and listen to the case in the first and last. Decisions made by the arbitrator is final and binding on the parties and shall be final. In the resolution of disputes that will be submitted to arbitration, BAPMI must comply with the four elements, are: Only civil disputes arising between the parties relating to the activities of the capital market, there is agreement among them that the dispute will be resolved by arbitration BAPMI, upon written request of one of BAPMI the parties to the dispute, the dispute is not a criminal and administrative cases, such as market manipulation, insider trading, suspension or revocation of business licenses.[28]

The most important requirement to apply for a settlement of the dispute to arbitration BAPMI is the first of a previous arbitration agreement between the parties to the dispute. Without the arbitration agreement, the dispute shall be submitted to BAPMI. Arbitration Agreement means the agreement / written agreement of the parties that the dispute between the parties will be resolved by arbitration BAPMI. Arbitration agreement can be formulated in one of the articles of the agreement made by the parties before a dispute arises (arbitration clause) or a separate agreement made by the parties after a dispute arises. Parties are already bound by the arbitration agreement is not entitled to file a dispute to the District Court and, in this case, the District Court is not permitted to resolve the dispute between the parties. the parties have been bound by the arbitration agreement.[29]

After that, the parties have been bound by the arbitration agreement and wants to resolve the dispute through arbitration BAPMI must submit a 
written request to the Chair and send it to the office BAPMI. Demand was filed by one of the disputing parties.[30] The parties filed an application called the "applicant", while others called the "respondent". Then, in connection with the arbitration request BAPMI which have been registered, BAPMI Board will examine a few points, such as:[28]

a. Whether the application meets the requirements of the administration?

b. Whether the parties have been bound by the arbitration agreement which indicated that the dispute be resolved through arbitration BAPMI?

c. Is the proposed dispute related to civil disputes related to activities in the field of capital market?

d. Does the applicant have to pay a registration fee?

If the application meets the administration requirements above, BAPMI will send a notice to the applicant and the defendant no later than 14 (fourteen) working days after the registration of that application has been received and will be processed further. The parties have the right to appoint the arbitrator and the arbitrator has the right to accept or reject the appointment. Arbitrators are people who because of their competence and integrity, chosen by the parties to the dispute to review and decide the dispute in question. Binding advisory opinion is issued by BAPMI notice at the request of the parties to provide interpretation of provisions that are not clear in the agreement. Binding opinion is in accordance with differences in the interpretation/interpretation contained in the agreement. Binding opinion of binding the parties request it. Therefore, any action contrary to the opinion of the binding is regarded as a denial of the promise.[30]

Mediation is the solution of disputes through negotiations with the help of mediators BAPMI chosen by the parties.[29] The mediator acts solely as facilitator of the negotiations and did not decide on the dispute. The reason is that the mediation efforts of the parties still wish to maintain their cooperation and continue to believe that they can solve them. They just need the presence of a mediator to facilitate negotiations. Therefore, mediation is considered successful if the parties can achieve peace[12]. Binding mediation agreement and must be registered at the local district court.[31] Therefore, it is considered that they are not carrying out the peace agreement did not keep their promises.

Mediation does not always work, maybe just one or both parties do not want to continue the negotiations. If this happens, the parties agreed to start the arbitration process BAPMI. Arbitration is a solution to the dispute by providing BAPMI arbitrator the authority to review and resolve disputes in the first and last.[28] Thus, the resulting output of the arbitration is the Decision/Arbitration Clause, and subsequently Decision/Clause will be brought to court to be registered by one of the parties to have the strength executorial. So, at the time of execution may be assisted by the Court.

Types of dispute resolution contained in BAPMI can be chosen by the parties in accordance with the needs, the characteristics of the dispute, and the expectations of the parties in the eventual solution. Alternative dispute resolution outside the court really meet the needs of market participants who wish to complete dispute was not prolonged. Decision/Arbitration Clause is divided into two kinds, are:[32]

\section{1) Pactum de compromittendo}

Pactum de compromittendo means.

The shape of this clause set out in Article 2 of Law No. 30, 1999, which reads

as follows:

"These laws regulate the settlement of a dispute or difference opinion of the parties to a legal relationship certain make arbitration agreement that expressly states that all disputes or differences of opinion arising or which may arise from the legal relationship will be settled by way of arbitration or through alternative settlement dispute"

\section{2) Acta Compromise}

Acta compromise is an arbitration agreement that made by the parties after the dispute arisen Article 9 paragraph (3) of Law No. 30, 1999 stated:

"The agreement deed of compromise must contain the problem of the dispute, the full name and place of residence, the full name and residence of the arbitrator or the arbitral tribunal, the arbitrator or the arbitral tribunal will take a decision, the full name of the secretary, period of dispute resolution, and the willingness of the parties dispute to bear all cost required for the settlement of disputes through arbitration." 


\subsection{The benefits of capital market disputes through the Indonesian Capital Market Arbitration Board (BAPMI)}

there are some benefits by choosing BAPMI to settle the capital market disputes.

\section{Time efficiency.[33]}

The time when the arbitration process will be faster and more efficient and flexible. Each dispute parties choose the arbitrator. Last trial conducted by an arbitrator. In this case, the arbitrator can freely set the agenda for the hearing by adjusting the time available to the parties. If the dispute is settled by the courts, new problems can be solved if the court has decided the case, appoint judges and appeal, so the resolution of cases take a long time. Not to mention if one of the parties is not satisfied with the decision of the court, one of the parties to appeal or appeal process that will take a long time.

The law requires the judiciary in Indonesia carried out simply, quickly, and cheaply.[34] But that mandate more distant than, litigation in court last long because the process is very long (an appeal, appeal, and PK) and concentrate various lots of cases on appeal and cassation.[34] As a result, the cost of the case being so very high. The process of settlement of the protracted and costly pose a risk to the public due to the inefficiencies of time and expense, and some businesses/activities to be blocked. In addition, the court proceedings are complex and rigid. This situation resulted in limitations justice court in providing services to the public.[35] Public access to justice is becoming increasingly isolated, not only for small communities, but also for almost all levels of society. In such circumstances, people are looking for alternatives to resolve the issue out of court.[36] Then comes the BAPMI as a new form of justice as a response to public concerns and offering various forms of Alternative Dispute Resolution to resolve the dispute out of court, particularly to resolve the dispute in the capital markets sector. in Indonesia.

In the latest development, ADR devolved conceptually not only because they have advantages over the court, not only because in practice they have proven to be an acceptable solution, not only because of the court and justice is becoming increasingly difficult. ADR development is also motivated by the increased attention to the issues of democratization, legal reform, a weak society, public interest, justice, rule of law, public accountability, public participation, and accountability. This development emphasizes the urgency of the optimization of the
ADR so that disputes can be settled in court to protect the interests of the people better, so that access to justice is always guaranteed.

\section{Confidentiality Dispute remains Secured/Confidentiality}

If through litigation conducted openly dispute resolution, arbitration conducted behind closed doors, arbitration is only attended by the litigants. In addition, the arbitration process is not no rules regarding evidence, if there is evidence would only be controlled by the arbiter, so that the parties feel safer and more comfortable, because the confidentiality of the company is that in priority in business activities. Arbitration institutions and arbitrators are bound sacred promise of confidentiality to all cases that are being handled, also with BAPMI, so it does not smell of cases handled by the media or the public.[37] In divulging the terms of business, it would be advantageous. The nature confidentiality/secret arbitration make alternative solution that adapts to the needs of the business world. Due to take place in private arbitration. Unlike the open method of general court litigation, arbitration relates only to the parties concerned, namely the litigant parties. This obviously makes litigants more comfortable. In the business world, business news related to the company's business dispute, will produce a precedent in one or both parties were litigants.[38]

\section{Free to choose arbitrators[30]}

In arbitration, parties are able to choose the arbitrators with particular matter expertise. This sort of thing cannot be found in other common courts. it means the process of settlement could be dealt with settlement-related domains. Due to the presence of the arbitrator in the settlement of disputes arising from the choice of the parties themselves, they should be able to choose a neutral arbiter so that there is no conflict of interest in the settlement of disputes.

\section{Cost-Effective}

Costs of resolving disputes through arbitration would have been cheaper for a shorter time spent and the process only involves Arbitration Institute. When in court proceedings, must go through a long process and takes so long, ranging from registering a case or a case to court, pay attorney and court costs. These costs will continue to increase if the losing party would appeal to a higher court or an appeal to the supreme court. As a result, there will be more costs are incurred and involved in resolving the case in the path of litigation, because the arbitration process, 
typically do not require a specific place and steps that so long as through litigation.

\section{Completed by the expert (Expert)[17]}

Complete a court case requires a lot of additional costs, because judges often encountered less able to handle the disputes that are technical in nature, so it requires an expert witness cost. In the settlement of disputes through BAPMI, all arbitrators are experts in their respective fields, so the arbitrator who directly handle a case is an arbitrator whose background is already an expert in the case, so it certainly felt easier in decision-making and is not detrimental to the parties.

\section{Arbitral awards is final and binding.}

According to Article 60 of Law No. 30 of 1999 on arbitration and alternative dispute resolution, an arbitral award is final and has a permanent legal power and bind binds the parties. Which means that after the dispute terminated, shall be submitted to the appeal, appeal, or reconsideration (PK), it is certainly different from the decision issued from the court or litigation, but the arbitration decision can be requested for cancellation if the parties has submitted to the court country where an arbitration award is thought to contain the following elements:

a) Letters or documents are filed in a recognized examination after adjudication counterfeit or otherwise is false

b) Once the decision is taken those documents which determine the hidden nature of the opposing party

c) Decision taken from the ruse carried out by one of the parties in the dispute

\section{CONCLUSION}

The advantageous of using arbitration in solving legal issues compared to formal court procedure is due to the limitation of the human resources of the law enforcer and the limitation of prison in Indonesia, Indonesia needs a new form of justice in order to resolve any dispute in Indonesia. ADR is not a new way to settle the dispute in Indonesia, however mostly businessmen still don't know exactly about it.. In Business industry, especially in capital market, the efficiency of time is important matter. BAPMI offers the best way in resolve dispute in capital market area. There are some advantages using BAPMI to solve/settle the capital market; those are: more efficient, confidential, cost-effective, free to choose arbitrators, completed by the expert (Expert), The verdict is final and binding. Author hope through this article people will know more about BAPMI and Author suggest that the government should increase the number of BAPMI council in Indonesia, it will be the best if people can find BAPMI in at least every province in Indonesia.

\section{REFERENCES}

[1] H. H. Dimyati, "Perlindungan Hukum Bagi Investor Dalam Pasar Modal," J. CITA Huk., 2014.

[2] A. S. Ningsih, Hukum Persaingan Usaha dan Geliat UMKM. Semarang: Fastindo, 2019.

[3] “KEPUTUSAN INVESTASI MASYARAKAT DI PASAR MODAL," $J$. Bisnis Darmajaya, 2019.

[4] S. D. Muniroh and U. Kamal, "THE INDICATION OF UNFAIR BUSINESS COMPETITION PRACTICE IN THE IMPLEMENTATION OF PUBLIC PROCUREMENT AUCTION USING ETENDERING," J. Priv. Commer. Law, 2018.

[5] R. U. Salami, "HUKUM PASAR MODAL DAN TANGGUNG JAWAB SOSIAL," $J$. Din. Huk., 2011.

[6] S. Sumani, C. W. Sandroto, and I. Mula, "PERILAKU INVESTOR DI PASAR MODAL INDONESIA," EKUITAS (Jurnal Ekon. dan Keuangan), 2017.

[7] M. A. Yaqin, "KONTRIBUSI PASAR MODAL SYARIAH TERHADAP PEMBANGUNAN HUKUM PASAR MODAL NASIONAL," LAW REFORM, 2010.

[8] A. Rahmawati and E. D. Suhardini, "Pengalihan Kepemilikan Saham Secara Melawan Hukum dalam Transaksi Repurchase Agreement (REPO)," Wacana Paramarta J. Ilmu Huk., 2018.

[9] A. S. Ningsih, D. D. Suprapti, and N. Fibrianti, "The Importance of Applying the Membership Value Toward Savings and Loans Cooperatives in Indonesia," Sriwij. Law Rev., vol. 3, no. 25, pp. 225-234, 2019.

[10] A. S. Ningsih and H. S. Disemadi, "Breach of contract: an Indonesian experience in akad credit of sharia banking," Ijtihad J. Wacana 
Huk. Islam dan Kemanus., vol. 19, no. 1, pp. 89-102, 2019.

[11] A. S. Ningsih, "Alternative Dispute Resolution as Soft Approach for Business Dispute in Indonesia,” 2019, vol. 363, no. 2nd International Conference on Indonesian Legal Studies (ICILS 2019), pp. 26-33.

[12] D. Latifiani, A. Widyawati, N. Fibrianti, and A. S. Ningsih, "Advocate as law enforcer in the implementation of e-court," Int. J. Innov. Creat. Chang., 2020.

[13] "Efektivitas Pembentukan Badan Arbitrase Pasar Modal (BAPMI) dalam Menunjang Kegiatan Pasar Modal," Ef. Pembentukan Badan Arbitr. Pasar Modal dalam Menunjang Kegiat. Pasar Modal, 2010.

[14] Cut Memi, "Implementasi Pembatalan Putusan BANI dan Putusan BAPMI Oleh Pengadilan Negeri," J. Yudisial, 2015.

[15] R. M. G. P. Soemartono, “Cara penyelesaian sengketa dan alternatif penyelesaian sengketa," Ilm. Ilmu Huk. "Era Hukum," 2014 .

[16] M. Irawan, "Penguatan Kerangka Hukum Terkait Penyelesaian Sengketa Pasar Modal Syariah Pada Pengadilan Agama," J. Huk. dan Peradil., 2016.

[17] BAPMI, "BAPMI Official Website." [Online]. Available: http://bapmi.org/en/index.php.

[18] S. Soekanto, Pengantar. 1986.

[19] J. Ibrahim, Teori \& Metodologi Penelitian Hukum Normatif, Malang. Malang: Banyumedia Publishing, 2005.

[20] R. Fitriani, Arbitrase dan alternatif penyelesaian sengketa di luar pengadilan. Yogyakarta: Deepublish, 2016.

[21] E. Entriani, “Arbitrase Dalam Sistem Hukum," An-Nisbah, 2017.

[22] A. A. Albar, "Dinamika Mekanisme Alternatif Penyelesaian Sengketa Dalam Konteks Hukum Bisnis Internasional," J. Huk. Kenotariatan, 2019.

[23] F. H. Winarta, Hukum penyelesaian sengketa : arbitrase nasional Indonesia dan internasional, Kedua, Cet. Jakarta: Sinar Grafika, 2016

[24] A. Entriani, “ARBITRASE DALAM SISTEM
HUKUM DI INDONESIA," An-Nisbah J. Ekon. Syariah, 2017.

[25] “ARBITRASE MERUPAKAN UPAYA HUKUM DALAM PENYELESAIAN SENGKETA DAGANG INTERNASIOANAL,” LEX Soc., 2015.

[26] E. Hudiata, "REKONSTRUKSI HUKUM PENYELESAIAN SENGKETA PASAR MODAL SYARIAH: PENGUATAN ASPEK REGULASI UNTUK MEMBERIKAN KEPASTIAN HUKUM," J. Huk. dan Peradil., 2017.

[27] BAPMI, PERATURAN BADAN ARBITRASE PASAR MODAL INDONESIA NOMOR: O1/BAPMI/12.2014 TENTANG PERATURAN DAN ACARA PENDAPAT MENGIKAT. .

[28] BAPMI, PERATURAN BADAN ARBITRASE PASAR MODAL INDONESIA NOMOR: PERO1/BAPMI/05.2016 TENTANG PERUBAHAN PERTAMA PERATURAN BADAN ARBITRASE PASAR MODAL INDONESIA NOMOR: 04/BAPMI/12.2014 TENTANG PERATURAN DAN ACARA ARBITRASE TANGGAL 19 DESEMBER 2014. .

[29] BAPMI, PERATURAN BADAN ARBITRASE PASAR MODAL INDONESIA NOMOR: O2/BAPMI/12.2014 TENTANG PERATURAN DAN ACARA MEDIASI. .

[30] BAPMI, PERATURAN BADAN ARBITRASE PASAR MODAL INDONESIA NOMOR: O4/BAPMI/12.2014 TENTANG PERATURAN DAN ACARA ARBITRASE. .

[31] N. V. Ariani, "Alternatif Penyelesaian Sengketa Bisnis Di Luar Pengadilan (Non Litigation Alternatives Business Dispute Resolution)," Rechts Vinding, 2012.

[32] “Arbitrase Sebagai Alternatif Solusi Penyelesaian Sengketa Bisnis di Luar Pengadilan," Pandecta Res. Law J., 2013.

[33] A. Suran Ningsih, “Alternative Dispute Resolution as Soft Approach for Business Dispute in Indonesia," 2019.

[34] KITAB UNDANG-UNDANG HUKUM ACARA PERDATA.

[35] M. Situmorang, "Pelaksanaan Putusan Arbitrase Nasional di Indonesia," J. Penelit. Huk. Jure, 2017.

[36] A. L. Prakoso, "TINJAUAN TERHADAP ARBITRASE SYARIAH SEBAGAI 
ALTERNATIF PENYELESAIAN

SENGKETA DI BIDANG PERBANKAN

SYARIAH,” J. Jurisprud., 2017.

[37] BAPMI, ETIKA PERILAKU (CODE OF CONDUCT) ARBITER/MEDIATOR BADAN ARBITRASE PASAR MODAL INDONESIA. .

[38] "Penyelesaian Sengketa Bisnis Syariah," Mimb. Huk., 2010. 